\section{SOI: $1.1 /$ TAS DOI: $10.15863 /$ TAS International Scientific Journal Theoretical \& Applied Science}

p-ISSN: 2308-4944 (print) e-ISSN: 2409-0085 (online)

Year: 2017 Issue: 12 Volume: 56

Published: $30.12 .2017 \quad \underline{\text { http://T-Science.org }}$

SECTION 12. Geology. Anthropology. Archaeology.
Oksana V. Akulich

Department of Economics, North-Eastern State University, Magadan, Russian Federation aku-oksana@mail.ru

Elnur Latif oglu Hasanov Corresponding member of International Academy of Theoretical and Applied Sciences, Ph.D., Senior specialist of Ganja Department Azerbaijan National Academy of Sciences, Ganja, Azerbaijan el-hasanov@mail.ru

\title{
SOME ISSUES OF RESEARCH OF POTENTIAL OF RENEWABLE ENERGY SOURCES
}

\begin{abstract}
Renewable energy resources is a numerate and quantitative text covering subjects of proven technical and economic importance worldwide. Energy supply from renewable is an essential component of every nation's strategy, especially when there is responsibility for the environment and for sustainability. Based on the various sources and scientific materials, also comparative research methods in this scientific article for the first time have been systematically investigated the main innovative issues of research of renewable energy resources of Azerbaijan as an important springs.

Key words: Azerbaijan, scientific researches, renewable resources, energy-efficient potential.

Language: English

Citation: Akulich OV, Hasanov EL (2017) SOME ISSUES OF RESEARCH OF POTENTIAL OF RENEWABLE ENERGY SOURCES. ISJ Theoretical \& Applied Science, 12 (56): 221-224.

Soi: http://s-o-i.org/1.1/TAS-12-56-35 Doi: crossef https://dx.doi.org/10.15863/TAS.2017.12.56.35
\end{abstract}

\section{Introduction}

The use of renewable and ecological energy sources, along with saving large quantities of fuel burned at thermal power plants, also significantly reduces the amount of harmful emissions into the environment. The use of alternative energy sources by using the country's natural potential paves the way for progressive changes in the future development directions of the electric power industry. Azerbaijan has favorable opportunities and renewable natural resources in terms of its inexhaustible energy potential. The use of alternative energy sources is more promising in areas where this potential is high and that traditional fuel resources are lacking [1, p. 116; 21, p. 299].

The main purpose of using alternative energy sources at Ecological Park is to attract public attention to this energy. Thus, wide use of ecologically clean alternative sources of energy, with a special role in compliance with the principle of "zero waste" in accordance with SOCAR's "Environmental Policy" document, reducing the amount of harmful emissions into the environment and saving large quantities of natural fuel resources (SOCAR, "In harmony with nature", 2010). One of the main indicators that characterize the DPI is the indicator of energy production and consumption in the country. These indicators include general information on energy generation and consumption per capita, most important and most important of which are renewable, non-depleting alternative energy (traditional energy sources - wood, sun, wind, underground thermal waters, energy generated during laying and laying of water, biogas, alcohol and vegetable oils taken from plants, etc.).

The use of renewable energy in the world differs greatly from one another. The share of nonrenewable energy in the United States is $3.6 \%$, in Australia - 3.7\%, in France - 4.7\%, in Canada - 4.6\%, in Finland - 6.2\%. In Azerbaijan, especially in Absheron, the number of sunny and windy days, as well as the wind copy are very satisfactory for alternative energy production, so should be widely used.

Taking this into consideration, a special state program on alternative energy production is being developed and implemented at Absheron Peninsula and its vicinity. In developed countries, thermal waters are used as a major alternative source of energy. This effective method should be widely used in our country (northern, southern, Nakhchivan Autonomous Republic and other regions) as a large source of thermal waters. Having both the necessary conditions and strong personnel potential for the provision of our country with solar, wind, thermal waters and watercourses, provides an important guarantee for the wider use of these energy carriers in our country. 
Azerbaijan has recently joined a number of conventions and agreements that have great importance.

Biodiversity conservation, global climate change, ozone layer protection, and so on. Conventions are of great importance. These conventions are dedicated to issues of national, regional and global significance. From this point of view, the programs and projects implemented to prevent and reduce the number of low-water birds in the Caspian Sea, the smallest living in the world, and the decline in the number of valuable fish species (sturgeon, white fish, etc.) are of great importance. Among the existing international standards for environmental management and protection, it is now the driving force that is most primitive and known as the ISO 14000. In accordance with this standard, every organization operating in all spheres must continually ensure its application by preparing a "Environmental Management System".

\section{Materials and Methods}

The "State Program on Poverty Alleviation and Sustainable Development in the Republic of Azerbaijan for 2008-2015" confirms the activities that ensure the development of all sectors of the nonoil sector in the near future. The program focuses on the development of new generation capacities based on the use of renewable energy sources by establishing solar energy and small hydropower plants. It is recommended that periodic monitoring and financial sanctions should be applied to minimize negative impact on the environment. Within the framework of the program for sustainable management of the environment, existing monitoring of forest, water and land resources, sustainable biodiversity management and desertification, extensive utilization of renewable energy sources, integrated waste management, mountain and coastal zone, ecosystems, and environmental monitoring system and regulatory framework should be improved, and environmental awareness and awareness-raising measures should be implemented [2].

The program aims to create a Carbon Fund for financial support to enterprises to reduce greenhouse gas emissions, to minimize negative effects of climate change on the ecosystem, population health and the country's economy, and to prevent pollution of atmospheric emissions into larger cities, installation, and a range of activities aimed at the development of renewable energy sources. In terms of its geographical location, climatic conditions and economic infrastructure, Azerbaijan has great potential for the development of renewable energy sources. There are favorable conditions for the use of solar, wind, small hydropower and biomass resources [2, 5-6].
Compared with Germany and Denmark, which has achieved great success in the field of alternative energy, Azerbaijan has three more potential opportunities for developing this field. The main document adopted by the Government of Azerbaijan in the field of renewable energy sources is the "State Program on the Use of Alternative and Renewable Energy Sources". The main objectives set out in the program are to identify the potential of renewable energy sources in electricity generation, to increase the efficiency of using the country's energy resources by exploiting them, to provide additional jobs through the creation of new energy production facilities, increasing its power, thereby improving the country's energy security.

In recent years, numerous studies have been conducted to explore the potential of renewable energy in Azerbaijan. Solar, wind, hydro, biomass energy and decomposition energy are taken into account when evaluating the potential of using renewable energy sources in Azerbaijan based on the technical data provided in various reports. The climatic conditions of Azerbaijan create a great basis for the production of heat and electricity through solar energy. The XXI century has been regarded as the century of transition to alternative energy. For this purpose, alternative energy sources are widely available in developed countries around the world, with no refusal of traditional fuels. The fact that our country is joining this initiative is the most demanded day of the day. It also improves the ecological situation and plays a major role in preventing global warming.

\section{Conclusion}

Refusal from traditional fuels and their transfer to alternative types of energy, serves to improve the ecological situation, ensure human health and prevent environmental pollution, minimize carbon, sulfur and nitrogen contamination in the atmosphere. The main purpose of the transition to alternative energy is to prevent humanity from facing ecological disasters and to protect our planet from severe crises and natural disasters. Otherwise, mankind will be threatened by two ways - to live, to survive, or to destroy.

As the main indicator of the Human Development Outlook, the environmental situation, energy resources, their biosphere and ecologically harmless to human health are taken into account. Greater importance is given to ecologically clean and pure energy resources. Energy resources are a key indicator of the country's economic development and are part of the state policy. It is forecasted that energy consumption will be 15 times higher than in the previous one in 2050 and $80 \%$ of the Earth's existing energy resources.

Thermal power stations, which are considered to be a good source of energy in all the countries of the 
world, but ecologically dangerous, have had a negative impact on the ecological situation of our planet. Each kilowatt creates an atmosphere of 30 kilograms of sulfur dioxide per day, $3 \mathrm{~kg}$ of carbon dioxide and $2,4 \mathrm{t}$ of ash, contaminating the atmosphere, damaging the ozone layer, creating a heat effect, and breaking heat exchange between the Earth's atmosphere and the atmosphere, generates global climate volatility causing severe environmental consequences [4, p. 5].

Solar energy recently, helio-energy (solar energy) is considered to be a very promising method in developed countries of the world (USA, Japan, Turkey, England, France, Germany, Russia, etc.). This type of energy is used in all areas of the Earth, is environmentally safe, endless and inexhaustible, has no negative impact on the environment, it does not cause difficulties to convert it to thermal energy by direct absorption and absorption with semiconductor photovoltaic modifiers. Establishing power plants with a capacity of up to $3000 \mathrm{KW}$ in solar power can save about 13,000 tons of fuel a year and reduce carbon dioxide in the atmosphere by up to
23,000 tons. At the moment, unmanned taxis are produced in the United Arab Emirates. They will still be used between Abu Dhabi terminals. These taxis will be made in the new Masdar Ekosaur, which is completely free of ecologically clean and polluting gases. As Masdar is a very modern city, it will be the only city in the world where there is no car yet. Built with the investment and financial support of many countries around the globe, this city will be the only environmentally friendly and the only city in the world, with a huge flow of tourists coming to the richest city of the city. Climate conditions of Azerbaijan allow producing heat and electricity by using solar energy. The annual number of sunny hours in the United States and Central Asia is 25003000 and 500-2000 in Russia, whereas 2400-3200 in Azerbaijan. The use of solar energy would help solve energy problems in several regions of Azerbaijan. In recent years, some developed countries in the world have begun to implement extensive photovoltaic programs (PVRs). The involvement of Azerbaijan in that program can play an important role in the application of such energy systems.

\section{References:}

1. Ayres RU (2007) On the practical limits to substitution. Ecological Economics, 61, 115128. doi:10.1016/j.ecolecon.2006.02.011.

2. Azerbaijan reveals potential of renewable energy sources Available: https://www.azernews.az/business/101789.html (Accessed: 10.12.2017).

3. Cherubini A, Papini A, Vertechy R, Fontana M (2015) Airborne wind energy systems: A review of the technologies. Renewable and Sustainable Energy Reviews, 51(11), 14611476.

4. Davidsson S, Höök M, Wall G (2012) A review of life cycle assessments on wind energy systems. Int. J. Life Cycle Assess, 17, 729-742. doi:10.1007/s11367-012-0397-8.

5. Dincer I (2000) Renewable energy and sustainable development: A crucial review. Renewable and Sustainable Energy Reviews, 4(2), 157-175.

6. Fajardo JM (2016) Evaluación de la Adopción del Programa de uso Racional y Eficiente de Energía en Iluminación, por Parte de Entidades Públicas con Base en Información Reportada al MME Durante los Años 2014 y 2015. Colombia: Universidad Distrital Francisco José de Caldas.
7. Geothermal Energy Association (2010) Green Jobs through Geothermal Energy.

8. Gubin EP (2005) State Regulation of Market Economy and Entrepreneurship: Legal Problems. Moscow: Lawyer.

9. Guerrero-Rodríguez NF, Rey-Boué AB, ReyesArchundia E (2017) Overview and comparative study of two-control strategies used in 3-phase grid-connected inverters for renewable systems. Renewable Energy Focus, 19(20), 75-89.

10. Guliyeva NM, Häsänov EL (2014) Die traditionelle Gändschänischen Teppiche von Zeitraum der Aserbaidschanischen Gelehrten und Dichter Mirsä Schäfi Waseh als ethnoanthropologische quelle (XIX Jahrhundert). European Applied Sciences, 2, pp. 3-5.

11. Hasanov EL (2016) Innovative basis of research of technologic features of some craftsmanship traditions of Ganja (On the sample of carpets of XIX century). International Journal of Environmental and Science Education, 11(14), pp. 6704-6714.

12. Hasanov EL (2015) Multidisciplinary approach to investigation of the basic handicraft branches of Ganja till the XX century. ISJ Theoretical \& 


\begin{tabular}{l|lr|ll|ll} 
& ISRA (India) & $=\mathbf{1 . 3 4 4}$ & SIS (USA) & $=\mathbf{0 . 9 1 2}$ & ICV (Poland) & $=\mathbf{6 . 6 3 0}$ \\
Impact Factor: & ISI (Dubai, UAE) $=\mathbf{0 . 8 2 9}$ & PUHЦ (Russia) $=\mathbf{0 . 2 0 7}$ & PIF (India) & $=\mathbf{1 . 9 4 0}$ \\
& GIF (Australia) & $\mathbf{0 . 5 6 4}$ & ESJI (KZ) & $=4.102$ & IBI (India) & $=\mathbf{4 . 2 6 0}$ \\
& JIF & $=\mathbf{1 . 5 0 0}$ & SJIF (Morocco) & $=\mathbf{2 . 0 3 1}$ & & \\
\hline
\end{tabular}

Applied Science 1(21): 7-15. DOI: http://dx.doi.org/10.15863/TAS.2015.01.21.2

13. Hasanov EL (2012) Innovational ethnographic facts on investigation and teaching of some basic decorative - applied arts of Ganja of the XIX - XX centuries / Applied and Fundamental Studies: Proceedings of the 1st International Academic Conference. - Saint Louis: Publishing House - Science and Innovation Center, Saint Louis, Missouri (the United States of America), p. 400-403.

14. Hasanov E.L. (2017) About research of features of legal culture on the basis of historical-literary heritage. Information (Japan), 20(4), pp. 22892296.

15. Hasanov EL (2015) To the Question on Research of Craftsmanship Traditions of Ganja of XIX - First Half of XX Centuries. Mediterranean Journal of Social Sciences, vol. 6, № 1, Part S1, pp. 433-437. Doi:10.5901/mjss.2015.v6n1s1p433

16. Häsänov EL (2012) Die Gändschänischen teppiche von XIX - XX Jahrhundert als geschichtliche - ethnographische quelle // European Science and Technology (Die Europäische Wissenschaft und die Technologien): 2nd International scientifi c conference. - Bildungszentrum Rdk e. V. Wiesbaden, p. 26-27.
17. Larsson S, Fantazzini D, Davidsson S, Kullander S, Höök M (2014) Reviewing electricity production cost assessments. Renewable and Sustainable Energy Reviews 30, 170-183. doi:10.1016/j.rser.2013.09.028.

18. Najmi A, Keramati A (2016) Energy consumption in the residential sector: Astudy on critical factors. International Journal of Sustainable Energy, 35(7), 645-663.

19. Nojedehi P, Heidari M, Ataei A, Nedaei M, Kurdestani E (2016) Environmental assessment of energy production from landfill gas plants by using long-range energy alternative planning (LEAP) and IPCC methane estimation methods: A case study of Tehran. Sustainable Energy Technologies and Assessments, 16, 33-42.

20. Sever R, Taşdemiroglu E (1986) Monthly and yearly average maps of total and direct solar radiation in Turkey. Solar Energy. Vol. 37, number 3. pp. 205-213.

21. Teleuyev GB, Akulich OV, Kadyrov MA, Ponomarev AA, Hasanov EL (2017) Problems of Legal Regulation for Use and Development of Renewable Energy Sources in the Republic of Kazakhstan. International Journal of Energy Economics and Policy, vol.7, № 5, pp. 296-301. 